\title{
"Wasteful" Public Spending and State Aid Control
}

\author{
Mathias Dewatripont, ECARES, ULB \\ Paul Seabright, IDEI, Toulouse
}

December 21, 2005

\begin{abstract}
The conventional academic rationale for supranational intervention to curb state aids to industry appeals to transfrontier spillovers. However, competition policy practitioners often speak in terms of curbing "wasteful" spending, regardless of whether or not any international spillovers are involved. Although it is often argued that such wasteful spending calls not for supranational state aid control but rather for better domestic political accountability, this paper argues that wasteful spending may be a by-product of accountability, not a symptom of its absence. Specifically, we describe a model in which politicians fund projects that are wasteful as a way to signal their diligence, and voters rationally reward them for this. We discuss implications for the role of state aid control mechanisms.
\end{abstract}

JEL codes: D72, D78, D82, H25

Author emails: mdewat@ulb.ac.be, Paul.Seabright@cict.fr

\section{Introduction}

State aid control is a paradox: in the name of protecting competition, a public authority intervenes in spending decisions taken by other public authorities-rather than in decisions taken by private firms, as in the rest of the domain of competition policy. What is the rationale for such intervention? The conventional answer to this question points to international spillovers: when markets are both international and imperfectly competitive, spending by a public authority in one country can subsidize its own economic activity at the expense of lost activity in another country. Therefore, the story goes, supranational intervention - by the European Commission or the WTO, as appropriate - may be needed to ensure that countries do not engage in a collectively wasteful "subsidy war". The problem arises because public authorities make spending decisions on the basis of narrowly national (or regional) interests, and the solution requires intervention by other public authorities that are capable of taking a more collective point of view. 
Although there is much to be said for this rationale, it captures rather poorly what competition policy practitioners (both competition agencies and the political authorities to which they are responsible) say when explaining their actions. Explanations are often couched in terms of curbing "wasteful" spending, regardless of whether or not any international spillovers are involved. The State Aid Action Plan launched in June 2005 by the European Commission, for example, talks of the need to aim for "less but better targeted" state aid. However, even if much state aid is indeed wasteful, in the absence of international spillovers it is hard to see why supranational intervention should be justified. Is not the waste of fiscal resources involved simply a matter of domestic political failure to be resolved by strengthening the mechanisms of domestic political accountability?

In this paper we argue that wasteful spending by politicians can sometimes arise as a by-product of mechanisms of political accountability, so that simply strengthening these same mechanisms would not necessarily improve - and might even worsen - the quality of spending decisions. The idea is that politicians sometimes engage in wasteful spending not out of negligence but rather out of a desire to improve their chances of re-election by signaling their commitment to supplying public goods. Funding projects, even wasteful ones, is a conspicuous way to signal this. We develop a model that shows (a) how this may be rational on the part of politicians, and (b) how the increased probability of re-election that follows from the wasteful spending decisions nevertheless reflects rational behavior on the part of voters, too. Voters reward conspicuous spending because it is evidence of effort on the part of politicians - even though it is associated, on average, with some degree of waste.

The paper is structured as follows. In section 2 we survey briefly the literature on the economic effects of state aids and the rationale for state aid control. Section 3 summarizes some evidence for the view that politicians often provide excessive subsidies to investment projects that create some public benefits (such as employment in depressed regions). Section 4 develops our model, and Section 5 discusses how to think of state aid control in the context of this model. Section 6 concludes.

\section{The rationale for state aid control}

The academic literature on interjurisdictional externalities identifies many reasons why government action to support economic activity in their own state will impinge on other states (see Besley \& Seabright 1999). Most relevant to state aid control is the literature on "strategic trade policy" (e.g. Brander and Spencer 1985), in which countries compete with each other in a game of individually rational but collectively wasteful subsidies to industry, spurred by the prospect of poaching each other's profits in imperfectly competitive markets. All countries are therefore better off if they can reach and enforce an agreement to forgo such subsidies. In these models, it makes no difference where firms choose to undertake their economic activity, so there is no purpose in governments competing to attract economic activity and there are no benefits from 
such competition to offset the possible costs. Instead inter-government activity is purely a form of rent shifting. Interpreted in the context of state aids, this means that subsidies to firms will consequently be higher than would be efficient and that the level of subsidized activity will higher than is efficient. ${ }^{1}$

Matters are very different in models in which mobility of firms between jurisdictions can have efficiency-enhancing properties. In a world without externalities and many jurisdictions, Tiebout (1956) proposed the notion that intergovernmental competition resulted in a virtuous sorting function. The Tiebout literature therefore emphasizes the benefits of decentralization in inducing jurisdictions to compete for sources of tax revenue by inducing citizens and firms to sort themselves into groups on the basis of their preferences for local public goods. Althoàugh Tiebout wrote about citizens, others (e.g. Oates \& Schwab 1991) have developed the analysis for firms. ${ }^{2}$

The new economic geography has provided another basis for thinking that there are externalities in the location of economic activity (see Neary 2001). In these models the location and production decisions of firms may have important external effects (congestion, job creation...) on their host economies, so that government action to internalize these externalities (by taxes, subsidies, or other means) is in principle justified even though the public policy conclusions are at best mixed. Regional or national governments can internalize some externalities through their actions, but others (notably those that spill across borders) will remain, and the results of inter-jurisdictional competition might be better or worse than prior to the intervention.

Overall, the most general conclusion that can be drawn from this literature is that, while the gains from intervention by regional or national governments to support private firms may be large or small according to circumstances, the only grounds for preventing such intervention (by state aid control at a supranational level) rest on the presence of a transfrontier externality that the normal processes of bargaining between governments and firms fail to internalize. The presumption, however, is that governments are acting to maximize the welfare of their own jurisdictions - or at least that, if they are not, then this is a domestic political failure that is at most indirectly related to the international competition between governments to attract firms. If such a presumption is not justified in practice, then the normative conclusions of this literature may not be justified either.

\footnotetext{
${ }^{1}$ This conclusion will be altered if there are independent reasons for thinking that subsidies in the absence of the externality would have been below the efficient level-e.g., because the activity in question was an international monopoly whose potential entrants did not take account of the beneficial externality their entry would create for consumers.

${ }^{2}$ Oates (1969) expounded the benefits of multijurisdictional policy making for somewhat different reasons. Decentralization allows different kinds and levels of public goods to be supplied in different localities, in a way assumed to be difficult for centralized governments to implement.
} 


\section{Wasteful spending: the evidence}

The evidence that governments often subsidize private firms in ways that do not maximize the welfare of their own jurisdictions comes from a variety of sources. Some of it is frankly anecdotal: expensive prestige projects such as Concorde, or the well-publicized state support to struggling firms such as Crédit Lyonnais, Alsthom, and MG Rover. Although strongly suggestive, such evidence is hard to evaluate. Does it represent more than the errors of judgment that frequently occur when industrial decisions are made, in the private and public sectors (as attested by private sector disasters like Vivendi Universal, Enron, and WorldCom)? Two more systematic kinds of evidence strengthen the case. First, there is econometric evidence that politicians and public officials tend to favor projects in relatively high-technology sectors, whether or not these are suitable for the comparative advantage of the location in question. A study by Midelfart-Knarvik and Overman (2002) showed that both national state aids and EU regional aid often failed to attract targeted industries to a significant degree because they did not take comparative advantage into account (e.g,. whether there was enough skilled labor in the workforce). Citizens therefore often failed to benefit from agglomeration economies. A second bias is that politicians frequently ignore the impact of one project on others. A study by Algan et al. (2002) showed that such impacts can be large: public employment can reduce private employment through general equilibrium effects. The last biennial report of the German Monopolkommission (2003) also discusses these harmful interproject effects at some length. And the study by Midelfart-Knarvik and Overman just cited suggests one route by which this could occur: subsidized projects could bid up the price of a scarce resource like skilled labor, making it less available for other firms.

The second kind of systematic evidence comes from recent studies showing the importance in industrial productivity growth of entry and exit of firms, precisely the processes that government subsidies to private firms tend to slow down - since these subsidies generally go to established firms rather than new entrants, and are hard to curtail if the projects fail. For instance, Hobijn and Jovanovic (2001) have shown not only that the US stock market recovery of the 1980s and 1990s was driven almost entirely by new firms, but also that incumbent firms of the early 1970s that did not take over or merge with new firms had still not recovered their market value relative to US GDP even by the end of the 1990s. Disney et.al. (2003) showed that half the growth of labor productivity in U.K. manufacturing 1980-92 was due not to internal growth of plants but instead to selection (the replacement of low-productivity plants by high-productivity plants). Moreover, $80-90 \%$ of total factor productivity growth was attributable to selection. ${ }^{3}$

Overall, it seems highly plausible that political processes driven by the desire for politicians to gain favorable press coverage may lead to spending decisions that incur costs that are out of proportion to the resulting economic benefits.

\footnotetext{
${ }^{3}$ See also Aghion and Howitt (2005) on the positive effect of exit of firms on economic growth.
} 
A recent case approved by the European Commission provides an interesting illustration. ${ }^{4}$ The Portuguese government approved aid worth $€ 41,5$ million (at 2000 prices) to the semiconductor firm Infineon in order to establish a plant manufacturing DRAM memory chips in Portugal. According to the firm's own estimates (plausibly erring on the optimistic side) the investment will generate 252 new jobs and safeguard 596 existing ones - a total of 848 at a cost of some $€ 49,000$ per job. Yet a study by Haskel et al. (2002) estimates that foreign direct investment generates productivity spillovers worth around $€ 3,500$ per job per year, so the project would have to continue for 25 years just to pay for itself - even discounting the possibility that Infineon's spillovers are lower than estimated (since there are no other DRAM manufacturers in Portugal). Does it really seem likely that Portugal's politicians are getting value for money? If not, then what is prompting them to spend money in this way?

In the next section we provide a simple model, drawn from Dewatripont \& Seabright (2005), that may help answer this question. ${ }^{5}$

\section{A model of conspicuous spending}

There is a project (think of it as a subsidy to attract a foreign firm) that has a cost $c$ and generates a value $v \in\{\underline{v}, \bar{v}\}$, which is observed by the politician and is not observed by the voters. Voters are risk neutral and care about $v-c$ (where $c$ can be considered as including the shadow cost of public funds). Hence, in the first-best outcome, the project should go ahead if and only if $v \geq c$; and to make the problem interesting, we assume that $\bar{v}>c>\underline{v}$.

However, the decision on the project's future is made by a politician, whose interests are not the same as those of the voters. We represent the politician's choice by $a \in\{0,1\}$, with $a=1$ meaning that the project is funded. Politicians care less about the benefits generated by the projects than voters do-for example, because politicians could alternatively use the money in ways that furthered their own interests more directly. There is, however, uncertainty about how much they do care, and this raises the possibility of adverse selection. Specifically, assume that the politician cares about $\alpha v$, where $\alpha \in\{\underline{\alpha}, \bar{\alpha}\}$, with probability $p$ that $\alpha=\bar{\alpha}$ and probability $(1-p)$ that $\alpha=\underline{\alpha}$, and $0<\underline{\alpha}<\bar{\alpha}<1$. Only the politician knows $\alpha$. In principle the $\bar{\alpha}$-type is the "better" politician from the point of view of the voters, though we shall show that this involves a subtle trade-off between moral hazard and adverse selection considerations.

Moral hazard arises because the politician must invest (at a cost) to find a good project. Let the probability that the politician finds a project with $v=\bar{v}$ be $i \in(0,1)$, where $i$ is her investment level. Investment $i$ costs her $\psi(i)$, which

\footnotetext{
${ }^{4}$ See the Commission decision at

http://europa.eu.int/eur-lex/lex/LexUriServ/LexUriServ.do?uri=OJ:L:2005:120:0005:0020:FR:PDF

${ }^{5}$ See Robinson and Torvik (2005) for a different model of equilibrium inefficient public projects where the inefficiency of the project is precisely what makes it attractive for politicians. Indeed, because the project is inefficient, it might be discontinued were the incumbent politician replaced by an opponent; this, in turn, prompts the voters who benefit from the project to vote for the incumbent politician.
} 
is increasing and convex in $i$. Assume also that all politicians care about reelection, which yields them a rent $B$. This kind of "career concerns" model of political motivation is standard in the literature (see Persson \& Tabellini 2000, Besley 2006).

Without allowing for the possibility of state aid control, which we discuss later, the timing of the model is as follows: At stage 0, Nature chooses $\alpha$; at stage 1 , the politician chooses $i$ and then learns $v$; at stage 2 , the politician decides whether to fund the project or not (i.e., chooses a); finally, at stage 3 , the voters decide whether or not to re-elect the politician.

Since the project generates returns too late to be verified in advance of the election, the re-election decision is made simply according to whether or not the project is funded. We assume for now that (a) if the project is funded then the politician is re-elected with a probability $r$, and (b) if it is not funded then she is not re-elected (more on this shortly). So the politician's problem is as follows:

$$
\underset{i}{\operatorname{Max}}\{i(\alpha \bar{v}+B r-c)+(1-i) \max [\alpha \underline{v}+B r-c, 0]-\psi(i)\} .
$$

To make effort worthwhile, this program incorporates the assumption that if $v=\bar{v}$ then the politician gains more from funding the project than from not funding it, which would yield her a payoff of 0 (no benefit, no cost, and no reelection). As for the case where $v=\underline{v}$, we make the following explicit assumption in order to investigate the possibility that politicians may "overbid" for projects:

$$
\bar{\alpha} \underline{v}+B r \geq c>\underline{\alpha v}+B r .
$$

This implies that a "bad" politician (one of type $\underline{\alpha}$ ) takes actions that are ex post efficient whereas a "good" politician (one of type $\bar{\alpha}$ ) overfunds due to re-election concerns, since she funds the low-value project and not just the high-value project. Nevertheless, voters may still rationally prefer to re-elect the type- $\bar{\alpha}$ politician even in the knowledge that she will overfund. The reason is that she will exert more effort than the bad politician, and the value of this effort may outweigh the efficiency cost of overfunding. Indeed, given condition (2), we can rewrite (1) for the good politician as

$$
\operatorname{Max}_{i}\{i(\overline{\alpha v}+B r-c)+(1-i)(\bar{\alpha} \underline{v}+B r-c)-\psi(i)\}
$$

which yields the first-order condition for effort $\bar{\alpha}(\bar{v}-\underline{v})=\psi^{\prime}(i)$. As for the bad politician, we can re-write 1 as:

$$
\underset{i}{\operatorname{Max}}\{i(\underline{\alpha} \bar{v}+B r-c)-\psi(i)\}
$$

which yields the first-order condition for effort $\underline{\alpha} \bar{v}+B r-c=\psi^{\prime}(i)$. Denoting by $\bar{i}$ and $\underline{i}$ the utility-maximizing choices of effort for the good and bad politician (respectively), it is straightforward to show that $\bar{i}>\underline{i}^{6}$

\footnotetext{
${ }^{6}$ To see this, note that $\bar{\alpha}(\bar{v}-\underline{v})>\underline{\alpha}(\bar{v}-\underline{v})=(\underline{\alpha} \bar{v}+B r-c)-(\underline{\alpha v}+B r-c)>$ $(\underline{\alpha} \bar{v}+B r-c)$, where the last inequality follows from assumption (2).
} 
Since voters do not internalize the effort cost of the politician, they strictly prefer more effort to less. This will outweigh the less efficient funding choices of the good politician - and thus lead voters to reward a politician who reveals herself to be good with greater probability - if and only if:

$$
\bar{i} \bar{v}+(1-\bar{i}) \underline{v}-c>\underline{i}(\bar{v}-c)
$$

where the left-hand (resp. right-hand) side represents the voter's gain with the $\bar{\alpha}$-type (resp. $\underline{\alpha}$-type) of politician. This condition will hold if and only if the expected gain from the higher probability of a good project outweighs the expected loss from overfunding by an over-zealous politician - that is, if and only if:

$$
(\bar{i}-\underline{i})(\bar{v}-c)>(1-\bar{i})(c-\underline{v}) .
$$

This is more likely to hold when: (i) $\bar{i}$ is high, so good politicians are relatively likely to find good projects; (ii) $\underline{i}$ is low, so bad politicians are relatively likely to find bad projects; (iii) $\bar{v}-c$ is high, so good projects are of relatively high value; and (iv) $c-\underline{v}$ is low, so bad projects are not too costly.

Our model is thus one in which politicians, owing to career concerns, undertake effort to attract foreign firms and thereby generate employment in their area. Voters are rightly impressed when these efforts are successful, leading them to revise upward their belief about the politican's quality, even though they understand that the process involves funding of some inefficient projects.

Clearly, our model is not the first one to look at the effect of career concerns on politicians' behavior. See in particular Persson and Tabellini (2000) and Rogoff and Siebert (1988) for discussions of the disciplining effects of career concerns on politicians. They have also stressed (albeit in different contexts than in our model) the potential negative effects of career concerns; Tthese can exacerbate a politician's incentive to raise distortive taxes in order to finance public goods that improve her standing in the eyes of voters.

\section{$5 \quad$ State aid control}

A natural way to view state aid control - investigated in Dewatripont and Seabright (2005) - is as an extra hurdle that publicly funded projects must clear in order to be finally approved. Modeling this requires specifying explicitly the incentives of the controlling agent (say, a European commissioner or DG-Competition) that makes the decision. For example, one can have this agent undertake effort to obtain verifiable information that would justify blocking the project, with the probability of finding this evidence being higher for a bad project but being still positive for a good project. Controllers can (like politicians) have career concerns and be rewarded for blocking projects, which is rational for voters to endorse because it increases beneficial effort even if it leads to decisions that are sometimes too strict. In such a setting, voters may be better off with a control regime that sometimes blocks good projects, provided: (i) it blocks bad projects 
sufficiently more often; (ii) bad projects are sufficiently costly: and (iii) there are enough bad projects relative to good projects.

Note that, provided the conditions for overbidding by good politicians hold, the voters are more likely to benefit from state aid control if there is a high proportion of good politicians selecting projects for funding! And although this is not modeled explicitly, it seems likely that the proportion of bad projects may be raised by international competition between governments that bid for investment projects by multinational firms, because such competition raises the share of the rent from any such projects that will be captured by the firms and lowers the share going to the bidding governments. Such increased competition doubtless accounts for the fact that the perceived need for state aid control has increased as international competition to attract foreign direct investment has intensified in recent years.

We can also note that this model captures one feature of the state aid control process that matches anecdotal descriptions by participants and enforcers in the European Union - namely that national politicians often welcome the pressure placed on them by the European Commission not to fund wasteful projects (while not wishing the fact that they welcome this pressure to be known in their own countries). This otherwise puzzling behavior has a natural explanation in the model: a politician funds wasteful projects not because she intrinsically wants them but rather because she want to send a signal about being a good type of politician. Of course, politicians want to send this signal regardless of which type they actually are, but it is more often incentive-compatible for the good types than the bad types to send it. However, if they can find some other way to send this signal then they will welcome the cancellation of the projects, whose costs are (by assumption) higher than the value that either type of politician places on their intrinsic benefits. Therefore, to the extent that a state aid control mechanism can signal to domestic voters that the politicians backing them are of the good type, the project cancellation will be a welcome outcome of the mechanism. Naturally, this cannot be expected to occur with certainty, for otherwise funding decisions by politicians would become purely cheap talk and would lose their signaling value.

Finally, is there anything intrinsically international about state aid control? Could not some domestic mechanism (an auditor-general or a "Cour des Comptes") act as controller? The answer is certainly that it could-provided it were sufficiently independent (and visibly so) of domestic political processes to provide the necessary check on domestic funding decisions. However, if there already exists an agency (e.g., the European Commission) that has the expertise necessary to examine state aids for the presence of international spillovers, then it is plausible that such an agency would be able, at relatively low cost, to provide the credible countervailing incentives that a controller would require. It thus makes sense for the two rather different functions to be exercised by the same statutory body, even if one of the functions is to counter the strictly domestic failures of the political process. 


\section{Conclusion}

There is substantial evidence suggesting that politicians often engage in wasteful spending on projects - projects, in other words, that generate real benefits to their host economies but at a disproportionate investment cost. The conclusion is often drawn that this phenomenon requires a strengthening of the mechanisms of domestic political accountability and has nothing to do with supranational state aid control. In this paper we argue that wasteful spending may be a byproduct of these mechanisms of accountability rather than a symptom of their absence. In such circumstances, simply strengthening accountability mechanisms would not solve the problem. State aid control should then be conceived as a necessary complement to such domestic accountability mechanisms; the state aid control mechanism need not be supranational, but it will often make sense for it to be so.

\section{Bibliography}

Aghion, Philippe and Peter Howitt (2005): "Appropriate Growth Policy: A Unifying Framework", Journal of the European Economic Association, this issue.

Algan, Yann, Pierre Cahuc and André Zylberberg (2002): "Public Employment and Labour Market Performance", Economic Policy no. 34, 7-65.

Besley, Timothy (2006): Principled Agents? The Political Economy of Good Government, book manuscript, London School of Economics.

Besley, Timothy and Paul Seabright (1999): "The Effects and Policy Implications of State Aids to Industry: An Economic Analysis", Economic Policy no. $34,13-53$.

Brander, James and Barbara Spencer (1985): "Export subsidies and International Market Share Rivalry," Journal of International Economics, 18 (1/2), 83-100.

Dewatripont, Mathias and Paul Seabright (2005): "A Theory of Wasteful Public Spending Projects", ECARES/IDEI, mimeo.

Disney, Richard, Jonathan Haskel and Ylva Heden (2003): "Restructuring and Productivity Growth in UK Manufacturing", Economic Journal, 113, 666694.

Haskel, Jonathan, S. Pereira and Matthew Slaughter (2002): "Does Inward Foreign Direct Investment Boost the Productivity of Domestic Firms?", NBER Working Paper no. 8724 .

Hobijn, Bart \& Boyan Jovanovic (2001): "The Information Technology Revolution and the Stock Market", American Economic Review, 91(5), 1203-1220.

Midelfart-Knarvik, Karen-Helene and Henry Overman (2002): "Delocation and European Integration: Is Structural Spending Justified?", Economic Policy no. $35,321-359$.

Monopolkommission (2003): "Competition Policy Under the Shadow of 'National Champions"', English summary of the Fifteenth Biennial Report of the Monopolkommission 2002/3. 
Neary, Peter (2001): "Of Hype and Hyperbolas: Introducing the New Economic Geography", Journal of Economic Literature, 39(2), 536-561.

Oates, Wallace (1969): "The Effects of Property Taxes and Local Public Spending on Property Values: an empirical study of tax capitalization and the Tiebout hypothesis", Journal of Political Economy, 77, 957-971.

Oates, Wallace and Robert Schwab (1991): "The Allocative and Distributive Implications of Local Fiscal Competition", in D. Kenyon \& J. Kincaid (eds): Competition Among States and Local Governments, Washington, D.C., The Urban Institute.

Persson, Torsten and Guido Tabellini (2000): Political Economics: Explaining Economic Policy, Cambridge, MA: MIT Press.

Tiebout, Charles M. (1956): "A Pure Theory of Local Expenditures", Journal of Political Economy, 6, 416-424.

Robinson, James A. and Ragnar Torvik (2005): "White Elephants", Journal of Public Economics, 89, 197-210.

Rogoff, Kenneth and Anne Siebert (1988): "Elections and Macroeconomic Policy Cycles", Review of Economic Studies, 55: 1-16. 